\title{
Reading and Critical Thinking Techniques on Understanding Reading Skills for Early Grade Students in Elementary School
}

\author{
Trio Ardhian \\ Corresponding author, Universitas Sarjanawiyata Tamansiswa, Indonesia, \\ trio.ardhian@ustjogja.ac.id
}

Inayatul Ummah

Institut Agama Islam Negeri Syekh Nurjati, Indonesia, inayummah@gmail.com

\section{Siti Anafiah}

Universitas Sarjanawiyata Tamansiswa, Indonesia, siti.anafiah@ustjogja.ac.id

\section{Reza Rachmadtullah}

Universitas PGRI Adi Buana, Indonesia, rezarachmadtullaheza@gmail.com

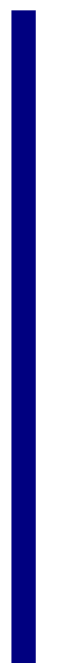

This study aims to determine the effect of reading and critical thinking techniques on students' reading comprehension skills. This study uses quantitative research methods with experimental methods with treatment with a $2 \times 2$ level design with 40 samples. The data used analysis variance and continued with Tukey and Least Square Differences (LSD) tests. The results showed that: (1) reading comprehension skills of students who learn to use reading techniques Directed Reading Thinking Activity is higher than students who learn to use reading techniques Preview, Question, Read, Reflect, Recite, and Review, (2) there is no interaction effect between reading and critical thinking techniques to students' reading comprehension skills, (3) for groups of students who think highly critically and use the technique of reading Directed Reading Thinking Activity higher than students who use reading techniques Preview, Question, Read, Reflect, Recite, and Review, (4) for groups of students who think critically low and use the techniques of reading Preview, Question, Read, Reflect, Recite, and Review are not higher than students who use the technique of reading Directed Reading Thinking Activity. Subsequent experiments are expected to find the right reading technique for students who think critically low on comprehension reading skills.

Keywords: reading techniques, critical thinking, reading comprehension skills, thinking techniques, early grade students

Citation: Ardhian, T., Ummah, I., Anafiah, S., \& Rachmadtullah, R. (2020). Reading and Critical Thinking Techniques on Understanding Reading Skills for Early Grade Students in Elementary School. International Journal of Instruction, 13(2), 107-118. https://doi.org/10.29333/iji.2020.1328a 


\section{INTRODUCTION}

Reading comprehension is one of the Indonesian language skills that must be developed at school. This is because understanding reading has become something essential and indispensable for students because of the success of students who largely depend on their ability to read. If students' reading comprehension is lacking, there is the possibility of failing in learning or at least students will experience difficulties in making progress (Somadayo, Nurkamto, \& Suwandi, 2013).

Reading has important benefits because reading can broaden one's horizons and knowledge (MS \& Rachmadtullah, 2018). Reading needs to be applied when children are as early as possible when children enter formal education institutions (Wigfield, Gladstone, \& Turci, 2016). By reading, students are expected to obtain various information, including content, and understand the meaning of reading. The fact that can be seen so far is the low reading skills of students because there are still many students who are lazy to read or the little interest in reading students (Hahnel, Goldhammer, Naumann, \& Kröhne, 2016).

The ability to read questions about the accuracy of the understanding of the words and their meanings, also questions the acceptance of the choice of words by others. That is because the community is bound by various colors that require that every word used must match the linguistic situation at hand (McGeown, Duncan, Griffiths, \& Stothard, 2015). In understanding a reading, knowledge about diction (word choice) that is less precise is very influential because if the way to understand the choice of words is not correct, it will affect the meaning of the reading. (Child, Cirino, Fletcher, Willcutt, \& Fuchs, 2019). To support it all it takes practice to arrange several sentences over and over again so that it can be more skilled in choosing the right words and can understand a reading in accordance with the concepts to be revealed (Castek \& Coiro, 2015).

Skills in reading, especially reading comprehension are very important for each student and cannot be negotiable (Oakhill, Cain, \& Nesi, 2016). This is based on an idea that most knowledge acquisition is done by students through reading activities (Lindeblad, Svensson, \& Gustafson, 2016). Reading comprehension is reading reading material by capturing sharper and deeper points of thought, so that it feels there is satisfaction after reading the material to completion (Pascual, Wassermann, Sadato, \& Hallett, 1995).

Skills in reading comprehension as a process of interaction between readers and texts in a reading event. Activity or reading where the emphasis is directed at skills and mastering the contents of the reading. Readers must be able to master and understand the reading they read. In this case, the element that must be present in every reading activity is understanding (Martin-Beltrán, Montoya-Ávila, García, Peercy, \& Silverman, 2019).

Understanding reading activities is an activity that aims to obtain in depth information and understanding of what is read. Reading comprehension is an understanding of the meaning or purpose in a reading through writing. This definition strongly emphasizes two main things in reading, namely the language it self and the graphic symbol of the writing that presents information in the form of reading (Anderson, 2019). So, someone 
who conducts reading comprehension activities must master the language or writing used in the reading that is read and is able to capture the information or content of the reading (Neumann, Padden, \& McDonough, 2019). To be able to understand the contents of a reading material well, it is necessary to have the ability to think critically in carrying out the ability to read and understand well (Soto et al., 2019). Understanding is one of the important aspects in reading activities, because in essence the understanding of reading material can improve reading skills themselves and for certain goals to be achieved. So, the ability to read can be interpreted as the ability to understand reading material. The purpose of reading is understanding not speed (Amin, 2019).

Reading comprehension is also defined as one type of reading that aims to understand the contents of the reading (MS \& Rachmadtullah, 2018). The ability to read is very complex and not only the ability to read it but also the ability to understand and interpret the contents of the reading. Based on some of the above meanings, a conclusion can be drawn simply that reading comprehension is a reading activity to understand the contents of the reading, both explicitly and implicitly from the reading material. Reading is a complex skill that involves a series of other smaller skills. In order for someone to be able to reach a level of understanding, he should experience a fairly long process. Therefore, we need to know and master some aspects of reading comprehension. The aspects of reading comprehension include: (a) understanding simple (lexical, grammatical, rhetorical) meanings, (b) understanding significance or meaning (al the author's intentions of relevance / cultural circumstances, reader reaction), (c) evaluation or assessment (content, form), (d) reading speed is flexible, which is easily adjusted to the situation (Torgerson, Brooks, Gascoine, \& Higgins, 2019). In reading comprehension, the reader is not only required to only understand and understand the contents of the reading, but he must also be able to analyze or evaluate and relate it to the experiences and initial knowledge he has (MS \& Rachmadtullah, 2018).

Reading comprehension also has certain goals to be achieved. The purpose of reading comprehension is to gain success in full understanding of logical arguments, etoris sequences or text patterns, symbolic patterns, emotional additional tones and also linguistic means used to achieve goals (MS \& Rachmadtullah, 2018; Tarigan, 2008; Wiguna, Dibia, \& Garminah, 2014) Based on the opinion above, it can be seen that the purpose of reading comprehension covers several things. Clearly reading comprehension is needed if we want to learn and understand the problems we read up to things that are very detailed.

Indonesian language subjects contain four components of language skills. Components of language skills include four aspects, namely: 1) listening skills; 2) speaking skills; 3) reading (reading skills); and 4) writing (writing skills) (Oakhill et al., 2016; Tarigan, 2008). The first language skills mastered by humans are listening and speaking then reading and writing (Mason, 2017). Listening and speaking skills are learned before entering the school level (MS \& Rachmadtullah, 2018), while reading and writing are learned when entering the level of education (Nurdiyanti \& Suryanto, 2010). Thus the four skills have a mutually supportive relationship between one another. In the learning process, the four language skills must be carried out in a balanced and integrated manner 
(McGeown, Osborne, Warhurst, Norgate, \& Duncan, 2016). Of the four language skills, reading skills require special attention in the schools in Indonesia. Reading is a basic skill that every student must possess, which must be mastered so that they can follow the entire learning process.

Directed Reading Thinking Activity is a comprehensive strategy that guides students in making questions related to the text, making predictions, then reading to accept or deny proving their predictions are wrong. The Process of the Directed Reading Thinking Activity encourages students to be active and the reader continues to improve their comprehension (Adlit, 2017). Preview, Question, Read, Reflect, Recite, and Review is a technique that focuses on students' efforts to understand reading texts independently, familiarize students with concentration in reading, practice speed reading skills, practice the power of forecasting with reading content, develop critical and comprehensive reading skills and remembering the reading material in private (Slavin, 2006).

Reading skills are needed to capture an information or ideas conveyed by the author through written text, and can interpret ideas found, both express and implied meaning of the text. (Slavin, Madden, Calderón, Chamberlain, \& Hennessy, 2011; Woolley, 2016). The process of reading comprehension is the process of making meaning from text. The aim is to obtain an overall understanding of what is explained in the text rather than to obtain the meaning of information content in the discourse so that an understanding of the discourse is read. (Duff, Tomblin, \& Catts, 2015). Reading comprehension requires a serious mind. Critical thinking is one of the factors that children need to understand reading. Children need critical thinking in analyzing, dissecting, classifying, distinguishing, matching, and taking the meaning implied in the reading. The role of critical thinking is important in understanding reading when a child is faced with a problem that needs to be solved.

Based on the literature and phenomena that have been described, in this study we want to test the hypothesis whether there is an Influence of Reading and Critical Thinking Techniques on Understanding Reading Skills for Early Grade Students in Elementary School. The results of this study are expected to be able to contribute to teachers in improving reading skills for elementary school students.

\section{METHOD}

\section{Research Design}

This study aims to determine the effect of reading and critical thinking techniques on students' reading comprehension skills. The research method used is quantitative research with the Anava 2 × 2 experimental method approach. Anova test is a special form of statistical analysis to test the comparison hypothesis of more than two groups. This study has three variables studied, namely the reading technique which acts as a treatment variable which is divided into two levels, namely the technique of reading Directed Reading Thinking Activity (A1) and reading Preview, Question, Read, Reflect, Recite, and Review Technique (A2). While the second independent variable is critical thinking which acts as a treatment variable divided by two levels of baggage, 
namely high critical thinking (B1) and low critical thinking (B2). The dependent variable is students' reading comprehension skills in Indonesian subjects.

\section{Participation}

The population in this study is a generalization area consisting of objects or subjects that have certain qualities and characteristics set by the researcher to be studied and then conclusions drawn (Sugiyono, 2012). The population of this study were students in grades IVa and IVb at the West Palimanan Elementary School 2 in Gempol District, Cirebon Regency, West Java. Samples are part of the number and characteristics of the population. Sampling technique is a sampling technique to determine the sample to be used in the study. The sampling used in this study is a random group sampling. This technique is used because the research will be conducted using two classes. The sample is class IV which amounts to two classes IVa and IVb. One class is treated with reading techniques through the Directed Reading Thingking Activity as the experimental class and one class is treated with reading techniques through Preview, Question, Read, Reflect, Recite, and Review as a control class.

\section{Instrument}

The instrument in this study consisted of two critical thinking variables and comprehension reading skills. For critical thinking variables consist of aspects: clarity, accuracy and accuracy of relevance, fairness of logical truths, and honesty. The results of the validity test of critical thinking instruments have calculated biserial correlation coefficients greater than the biserial correlation coefficient $\left(r_{x y}>0.361\right)$ then the instrument is said to be valid. The results of the calculated reliability test were compared with $r_{\text {table }}$ with a significance level of $5 \%$. If the price is calculated $>$ rtable, the questions tested have reliable criteria. Testing is done by comparing the reliability coefficient alpha cronbach with reliability coefficient criteria. If the cronbach alpha reliability coefficient is greater than the reliability coefficient criteria then it is said to be a reliable instrument. Further, as for the reading comprehension instrument rubric which consists of aspects: pre-reading stage, reading stage, and post-reading stage. The grading assessment of comprehension reading skills has a weight value of the prabaca stage aspects of $30 \%$, the reading stage of $30 \%$, and the post-reading stage of $40 \%$ which includes the rating categories very good, good, sufficient, and lacking.

\section{Data and Analysis}

To analyze the data in this study used two-way analysis of variance (ANOVA) with design treatment by level $2 \times 2$. In order for hypothesis testing to be carried out it is necessary to test the analysis requirements of the normality test and homogeneity test. Existing data is processed so that it has meaning that is useful to answer problems in research and to test hypotheses. Calculation is done using statistical software, the program used is a program to process statistical data, namely Statistical Package for Special Science (SPSS) 24. 


\section{FINDINGS}

This study used a $2 \times 2$ treatment by level experimental design with two independent variables, namely reading techniques and critical thinking skills. Hypothesis testing is done by using two-way variance analysis (2x2 ANOVA) to see the difference in the average main influencet and the interaction influencet. Based on the results of the calculation of two-way analysis of variance (ANAVA), the following conclusions can be drawn:

Differences in reading comprehension skills between students who learn the techniques of reading the Directed Reading Thingking Activity and techniques to read Preview, Question, Read, Reflect, Recite, and Review

The following table 1 regarding the results of hypothesis testing is done to determine the difference in reading comprehension skills through the treatment of the Directed Reading Thingking Activity and Preview techniques, Question, Read, Reflect, Recite, and Review:

Table 1

Influence Table of Treatment on Reading Comprehension Skills

\begin{tabular}{llllll}
\hline \multicolumn{6}{l}{ Tests of Between-Subjects Influences } \\
\hline Dependent Variable: MP & $\begin{array}{l}\text { Type III } \\
\text { Sum of Squares }\end{array}$ & df & $\begin{array}{l}\text { Mean } \\
\text { Square }\end{array}$ & F & Sig. \\
\hline Source & $6268.475^{\text {a }}$ & 3 & 2089.492 & 130.074 & .000 \\
Corrected & 212722.225 & 1 & 212722.225 & 13242.262 & .000 \\
Model & 6268.475 & 3 & 2089.492 & 130.074 & .000 \\
Trercept & 578.300 & 36 & 16.064 & & \\
Error & 219569.000 & 40 & & & \\
Total & 6846.775 & 39 & & & \\
Corrected & Total & & & & \\
\hline
\end{tabular}

Based on the calculation table above shows that the treatment done to students both through the Directed Reading Thinking Activity reading technique and the Preview, Question, Read, Reflect, Recite, and Review reading technique produces differences in reading comprehension skills. This is evidenced from the treatment value of 0,000 or $<0,05$. This means that hypothesis 1 is accepted.

Influenced of interaction between reading and critical thinking techniques on comprehension reading skills 
Table 2

Treatment and Critical Thinking Interactions

\begin{tabular}{llllll}
\hline \multicolumn{2}{l}{ Tests of Between-Subjects Influencets } & & & & \\
\hline Dependent Variable: MP & & & & & \\
\hline Source & Type III Sum of Squares & df & Mean Square & F & Sig. \\
\hline Corrected Model & $6688.442^{\mathrm{a}}$ & 21 & 318.497 & 36.208 & .000 \\
Intercept & 157288.611 & 1 & 157288.611 & 17881.232 & .000 \\
Treatment & 184.471 & 2 & 92.236 & 10.486 & .001 \\
Critical Thinking & 399.700 & 16 & 24.981 & 2.840 & .018 \\
Treatment * Critical & 27.138 & 2 & 13.569 & 1.543 & .241 \\
Thinking & 158.333 & 18 & 8.796 & & \\
Error & 219569.000 & 40 & & & \\
Total & 6846.775 & 39 & & & \\
Corrected Total & & & & \\
a. R Squared = .977 (Adjusted R Squared = .950) & & & & \\
\hline
\end{tabular}

Based on table 2 shows that the interaction of reading techniques through treatment carried out to students both through the Directed Reading Thingking Activity reading technique and the Preview, Question, Read, Reflect, Recite, and Review reading technique with critical thinking skills is indicated by a significance value of 0.241 . This means that the interaction between reading and critical thinking techniques does not affect reading comprehension skills or hypothesis 2 is not accepted.

Differences in groups of students who have high critical thinking skills in reading comprehension skills who learn the techniques of reading the Directed Reading Thingking Activity and students who learn by reading Preview, Question, Read, Reflect, Recite, and Review techniques

Table 3

Tuckey Test Results and Least Square Differences (LSD)

\begin{tabular}{|c|c|c|c|c|c|}
\hline \multicolumn{6}{|c|}{ Dependent Variable: MP } \\
\hline & (I) treatment & (j) treatment & Mean Difference (I-J) & Std. Error & Sig. \\
\hline \multirow{12}{*}{$\begin{array}{l}\text { Tukey } \\
\text { HSD }\end{array}$} & \multirow{3}{*}{$\mathrm{A}_{1} \mathrm{~B}_{1}$} & $\mathrm{~A}_{1} \mathrm{~B}_{2}$ & $24.10^{*}$ & 1.792 & .000 \\
\hline & & $\mathrm{A}_{2} \mathrm{~B}_{1}$ & $10.10^{*}$ & 1.792 & .000 \\
\hline & & $\mathrm{A}_{2} \mathrm{~B}_{2}$ & $32.50^{*}$ & 1.792 & .000 \\
\hline & \multirow{3}{*}{$\mathrm{A}_{1} \mathrm{~B}_{2}$} & $\mathrm{~A}_{1} \mathrm{~B}_{1}$ & $-24.10^{*}$ & 1.792 & .000 \\
\hline & & $\mathrm{A}_{2} \mathrm{~B}_{1}$ & $-14.00^{*}$ & 1.792 & .000 \\
\hline & & $\mathrm{A}_{2} \mathrm{~B}_{2}$ & $8.40^{*}$ & 1.792 & .000 \\
\hline & \multirow{3}{*}{$\mathrm{A}_{2} \mathrm{~B}_{1}$} & $\mathrm{~A}_{1} \mathrm{~B}_{1}$ & $-10.10^{*}$ & 1.792 & .000 \\
\hline & & $\mathrm{A}_{1} \mathrm{~B}_{2}$ & $14.00^{*}$ & 1.792 & .000 \\
\hline & & $\mathrm{A}_{2} \mathrm{~B}_{2}$ & $22.40^{*}$ & 1.792 & .000 \\
\hline & \multirow{3}{*}{$\mathrm{A}_{2} \mathrm{~B}_{2}$} & $\mathrm{~A}_{1} \mathrm{~B}_{1}$ & $-32.50^{*}$ & 1.792 & .000 \\
\hline & & $\mathrm{A}_{1} \mathrm{~B}_{2}$ & $-8.40^{*}$ & 1.792 & .000 \\
\hline & & $\mathrm{A}_{2} \mathrm{~B}_{1}$ & $-22.40^{*}$ & 1.792 & .000 \\
\hline \multirow{6}{*}{ LSD } & \multirow{3}{*}{$\mathrm{A}_{1} \mathrm{~B}_{1}$} & $\mathrm{~A}_{1} \mathrm{~B}_{2}$ & $24.10^{*}$ & 1.792 & .000 \\
\hline & & $\mathrm{A}_{2} \mathrm{~B}_{1}$ & $10.10^{*}$ & 1.792 & .000 \\
\hline & & $\mathrm{A}_{2} \mathrm{~B}_{2}$ & $32.50^{*}$ & 1.792 & .000 \\
\hline & \multirow{3}{*}{$\mathrm{A}_{1} \mathrm{~B}_{2}$} & A1B1 & $-24.10^{*}$ & 1.792 & .000 \\
\hline & & $\mathrm{A}_{2} \mathrm{~B}_{1}$ & $-14.00^{*}$ & 1.792 & .000 \\
\hline & & $\mathrm{A}_{2} \mathrm{~B}_{2}$ & $8.40^{*}$ & 1.792 & .000 \\
\hline
\end{tabular}




\begin{tabular}{cllll}
\hline Dependent Variable: MP & & & & \\
\hline \multirow{2}{*}{ (I) treatment } & (j) treatment & Mean Difference (I-J) & Std. Error & Sig. \\
\hline \multirow{2}{*}{$\mathrm{A}_{2} \mathrm{~B}_{1}$} & $\mathrm{~A}_{1} \mathrm{~B}_{1}$ & $-10.10^{*}$ & 1.792 & .000 \\
& $\mathrm{~A}_{1} \mathrm{~B}_{2}$ & $14.00^{*}$ & 1.792 & .000 \\
& $\mathrm{~A}_{2} \mathrm{~B}_{2}$ & $22.40^{*}$ & 1.792 & .000 \\
\hline \multirow{2}{*}{$\mathrm{A}_{2} \mathrm{~B}_{2}$} & $\mathrm{~A}_{1} \mathrm{~B}_{1}$ & $-32.50^{*}$ & 1.792 & .000 \\
& $\mathrm{~A}_{1} \mathrm{~B}_{2}$ & $-8.40^{*}$ & 1.792 & .000 \\
& $\mathrm{~A}_{2} \mathrm{~B}_{1}$ & $-22.40^{*}$ & 1.792 & .000 \\
\hline
\end{tabular}

Based on the calculation of the table above the differences in groups of students who have high critical thinking skills in reading comprehension skills who learn with Directed Reading Thingking Activity reading techniques and students who learn with Preview, Question, Read, Reflect, Recite, and Review reading techniques can be seen in columns A1B1 and A2B1. Based on the results of the Tuckey Test and the Least Square Differences (LSD) Test the average difference value indicates that the group of students who have high critical thinking skills in reading comprehension skills who learn with the Directed Reading Thingking Activity reading technique have a higher score, which is indicated by a difference of 10,10 and a significance value of 0,000 , meaning that hypothesis 3 is accepted.

Differences in groups of students who have critical thinking skills are low in reading comprehension skills who learn with the techniques of reading the Directed Reading Thingking Activity and students who learn by reading Preview, Question, Read, Reflect, Recite, and Review techniques

To find out the differences in groups of students who have low critical thinking skills in reading comprehension skills who learn with Directed Reading Thingking Activity reading techniques and students who learn with Preview, Question, Read, Reflect, Recite, and Review reading techniques can be seen in columns A1B2 and A2B2. Based on the results of the Tuckey test and the Least Square Differences (LSD) test the average difference value indicates that the group of students who have low critical thinking skills in reading comprehension skills who learn with the Directed Reading Thingking Activity reading technique have a higher score, which is indicated by a difference of 8,40 and a significance value of 0,000 . and means that hypothesis 4 is accepted.

\section{DISCUSSION}

Based on the results of hypothesis testing shows that there is no influence of interaction between reading and critical thinking techniques on reading comprehension skills. This shows that although the reading and critical thinking techniques partially influence the reading comprehension skills, the interaction of the two variables does not have an impact on the change in reading comprehension skills of the fourth grade students. This can be seen from the frequency of the score scores of the reading comprehension skills obtained by students given treatment (reading) the technique of reading Directed Reading Thinking Activity and having high and low critical thinking skills shows a higher score than students given treatment read Preview, Question, Read, Reflect, 
Recite, and Review and have high and low critical thinking skills. Therefore, the interaction between the reading techniques of the Directed Reading Thinking Activity and the techniques of reading Preview, Question, Read, Reflect, Recite, and Review with high and low critical thinking skills did not have a significant change in students' reading comprehension skills.

Based on the results of hypothesis testing shows that there are differences in reading comprehension skills in groups of students who have high critical thinking skills with reading Directed Reading Thinking Activity techniques and students who learn by reading Preview, Question, Read, Reflect, Recite, and Review techniques. In accordance with the theory that the reading technique of the Directed Reading Thinking Activity has a better advantage in creating students' reading comprehension skills. Students who are given treatment by using the reading technique Directed Reading Thinking Activity behave in understanding the reading of the text and are able to make predictions related to the contents of the reading in the text. These results are consistent with the research Somadayo et al., (2013) which proves that the Directed Reading Thinking Activity strategy is a better strategy in improving students' reading skills. Students who have a high reading interest show comprehensive reading skills compared to students who have low reading interest. This is also reinforced by the results of research by Riana Novita, Bachtiar and Barus, that students play a role, are enthusiastic and actively participate in teaching reading, especially during Directed Reading Thinking Activity activities, as well as an increase in student learning achievement seen from the test scores. Bariska and Hariani also prove that the Directed Reading Thinking Activity strategy can improve understanding reading skills (Bariska, 2013). But these results are not consistent with Connie Eilar Renn, which shows that there are no differences in student achievement using either the Directed Reading Activity method or the Directed Reading Thinking Activity method. (Renn, 1999).

Based on the results of hypothesis testing shows that there are differences in reading comprehension skills in groups of students who have low critical thinking skills with reading Directed Reading Thinking Activity techniques and students who learn by reading Preview, Question, Read, Reflect, Recite, and Review techniques. In accordance with the theory that the reading technique of the Directed Reading Thinking Activity has a better advantage in creating students' reading comprehension skills. With the low critical thinking skills possessed by students, but the score of the results of reading comprehension skills of students who are given treatment Directed Reading Thinking Activity shows a higher value. These results are consistent with Fahim and Sa'eepor who showed that there were no differences in critical thinking between the 2 groups in comprehensive reading (Fahim \& Sa'eepour, 2011). But these results are not consistent with Aloqaili who found evidence that there is a relationship between critical thinking and comprehensive reading (Aloqaili, 2012). (Vaseghi \& Barjesteh, 2012) also proves that critical thinking skills influence the ability to read comprehensively and show that critical thinking skills help students improve their comprehensive reading skills. 


\section{CONCLUSION}

The findings in this study are that the learning reading technique of the Directed Reading Thinking Activity has more influencetive influencet compared to the reading, learning, read, reflect, recite, and review learning techniques for reading comprehension skills. This is indicated by the average score of students' reading comprehension skills of high critical thinking groups who use the Directed Reading Thinking Activity reading technique that is higher than the average reading comprehension skill score of students using the techniques of reading Preview, Question, Read, Reflect, Recite, and Review. Directed Reading Thinking Activity is the most appropriate reading technique used in improving students' reading comprehension skills. The technique of reading the Directed Reading Thinking Activity can be used in groups of students who have high critical thinking skills. Techniques to read the Directed Reading Thinking Activity and Preview, Question, Read, Reflect, Recite, and Review can be used in groups of students who have low critical thinking skills. Because the average score of reading comprehension skills of students who have low critical thinking skills by using the Directed Reading Thinking Activity reading technique is lower than the technique of reading Preview, Question, Read, Reflect, Recite, and Review, it cannot be proven statistically but significantly.

\section{REFERENCES}

Aloqaili, A. S. (2012). The relationship between reading comprehension and critical thinking: A theoretical study. Journal of King Saud University - Languages and Translation, 24(1), 35-41. https://doi.org/10.1016/j.jksult.2011.01.001.

Amin, M. R. (2019). Developing reading skills through influencetive reading

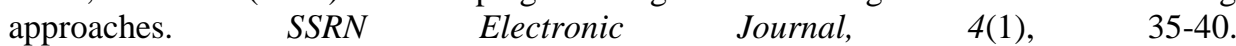
https://doi.org/10.2139/ssrn.3342538.

Anderson, N. J. (2019). Integration with other language skills. In The TESOL Encyclopedia of English Language Teaching (pp. 1-7). John Wiley \& Sons. https://doi.org/10.1002/9781118784235.eelt0473.

Bariska, H. F. (2013). Penerapan strategy direct reading thinking activity ( DRTA ) untuk Meningkatkan Keterampilan Membaca Pemahaman Siswa Kelas V. JPGSD, Volume 01, 0-216.

Castek, J., \& Coiro, J. (2015). Understanding what students know. Journal of Adolescent \& Adult Literacy, 58(7), 546-549. https://doi.org/10.1002/jaal.402.

Child, A. E., Cirino, P. T., Fletcher, J. M., Willcutt, E. G., \& Fuchs, L. S. (2019). A Cognitive dimensional approach to understanding shared and unique contributions to reading, math, and attention skills. Journal of Learning Disabilities, 52(1), 15-30. https://doi.org/10.1177/0022219418775115.

Duff, D., Tomblin, J. B., \& Catts, H. (2015). The influence of reading on vocabulary growth: A case for a matthew influencet. Journal of Speech, Language, and Hearing Research, 58(3), 853-864. https://doi.org/10.1044/2015_JSLHR-L-13-0310. 
Fahim, M., \& Sa'eepour, M. (2011). The impact of teaching critical thinking skills on reading comprehension of Iranian EFL learners. Journal of Language Teaching and Research, 2(4), 867-874. https://doi.org/10.4304/jltr.2.4.867-874.

Hahnel, C., Goldhammer, F., Naumann, J., \& Kröhne, U. (2016). Influencets of linear Reading, basic computer skills, evaluating online information, and navigation on reading digital text. Computers in Human Behavior, 55, 486-500. https://doi.org/10.1016/j.chb.2015.09.042.

Lindeblad, E., Svensson, I., \& Gustafson, S. (2016). Self-concepts and psychological well-being assessed by beck youth inventory among pupils with reading. difficulties. Reading Psychology, 37(3), 449-469. https://doi.org/10.1080/02702711.2015.1060092.

Martin-Beltrán, M., Montoya-Ávila, A., García, A. A., Peercy, M. M., \& Silverman, R. (2019). 'Time for una pregunta': Understanding Spanish use and interlocutor response among young English learners in cross-age peer interactions while reading and discussing text. International Journal of Bilingual Education and Bilingualism, 22(1), 17-34. https://doi.org/10.1080/13670050.2018.1515176.

Mason, J. M. (2017). Reading stories to preliterate children: A proposed connection to reading. In P. B. Gough, L. C. Ehri, \& R. Treiman (Eds.), Reading Acquisition (pp. 215-241). Routledge. https://doi.org/10.4324/9781351236904-8.

McGeown, S. P., Duncan, L. G., Griffiths, Y. M., \& Stothard, S. E. (2015). Exploring the relationship between adolescent's reading skills, reading motivation and reading habits. Reading and Writing, 28(4), 545-569. https://doi.org/10.1007/s11145-014-95379.

McGeown, S. P., Osborne, C., Warhurst, A., Norgate, R., \& Duncan, L. G. (2016). Understanding children's reading activities: Reading motivation, skill and child characteristics as predictors. Journal of Research in Reading, 39(1), 109-125. https://doi.org/10.1111/1467-9817.12060.

MS, Z., \& Rachmadtullah, R. (2018). Constructivism approach in learning to write narrative at elementary school. 1st International Conference on Innovation in Education (ICoIE 2018), 287-290. https://doi.org/10.2991/icoie-18.2019.64.

Neumann, H., Padden, N., \& McDonough, K. (2019). Beyond English language proficiency scores: Understanding the academic performance of international undergraduate students during the first year of study. Higher Education Research \& Development, 38(2), 324-338. https://doi.org/10.1080/07294360.2018.1522621.

Nurdiyanti, E., \& Suryanto, E. (2010). Pembelajaran Literasi Mata Pelajaran Bahasa Indonesia pada Siswa Kelas V Sekolah Dasar. Paedagogia, 13(2).

Oakhill, J., Cain, K., \& Nesi, B. (2016). Understanding of idiomatic expressions in context in skilled and less skilled comprehenders: Online processing and interpretation. Scientific Studies of Reading, 20(2), 124-139. https://doi.org/10.1080/10888438.2015.1092973. 
Pascual, A., Wassermann, E. M., Sadato, N., \& Hallett, M. (1995). The role of reading activity on the modulation of motor cortical outputs to the reading hand in braille readers. Annals of Neurology, 38(6), 910-915. https://doi.org/10.1002/ana.410380611.

Renn, C. E. (1999). The effects of the directed reading thinking activity on second grade reading comprehension (Unpublished master thesis). Grand Valley State University.

Slavin, R. E. (2006). Educational psychology: Theory and practice. Pearson.

Slavin, R. E., Madden, N., Calderón, M., Chamberlain, A., \& Hennessy, M. (2011). Reading and language outcomes of a multiyear randomized evaluation of transitional bilingual education. Educational Evaluation and Policy Analysis, 33(1), 47-58. https://doi.org/10.3102/0162373711398127.

Somadayo, S., Nurkamto, J., \& Suwandi, S. (2013). The influencet of learning model DRTA (Directed Reading Thingking Activity) toward students' reading comprehension ability seeing from their reading interest. Journal of Education and Practice, 4(8), 115 123.

Soto, C., Gutiérrez de Blume, A. P., Jacovina, M., McNamara, D., Benson, N., \& Riffo, B. (2019). Reading comprehension and metacognition: The importance of inferential $\begin{array}{llll}\text { skills. Cogent } & \text { Education, } & 6(1), & 1565067 .\end{array}$ https://doi.org/10.1080/2331186X.2019.1565067.

Sugiyono. (2012). Metode Penelitian Kuantitatif, Kualitatif, dan R\&D. Bandung: Alfabeta.

Tarigan, H. G. (2008). Membaca. Jakarta: Angkasa.

Torgerson, C., Brooks, G., Gascoine, L., \& Higgins, S. (2019). Phonics: Reading policy and the evidence of influencetiveness from a systematic 'tertiary' review. Research Papers in Education, 34(2), 208-238. https://doi.org/10.1080/02671522.2017.1420816.

Vaseghi, R., \& Barjesteh, H. (2012). Critical thinking: A reading strategy in developing english reading comprehension performance. Sheikhbahaee EFL Journal, 1(2), 21-34. Retrieved from http://shbu.ac.ir/efl/efl2/2.pdf.

Wigfield, A., Gladstone, J. R., \& Turci, L. (2016). Beyond cognition: Reading motivation and reading comprehension. Child Development Perspectives, 10(3), 190195. https://doi.org/10.1111/cdep.12184.

Wiguna, I. W. R., Dibia, K., \& Garminah, N. N. (2014). Pengaruh Strategi DRTA (Directed Reading Thinking Activity) Terhadap Hasil Belajar Membaca Intensif Siswa Kelas IV Semester 1 SD Gugus Belantih Kecamatan Kintamani Tahun Pelajaran 2013 / 2014 Jurusan Pendidikan Guru Sekolah Dasar, FIP.

Woolley, G. (2016). Reading comprehension intervention for high-functioning children with autism spectrum disorders. Australian Journal of Learning Difficulties, 21(1), 4158. https://doi.org/10.1080/19404158.2016.1190770. 